\title{
INFLUENCES OF DEMOGRAPHIC AND PSYCHOGRAPHICS ON \\ Consumer PAYMent PREFERENCES
}

\section{Charles H. Rader}

\section{Matiur Rahman}

\author{
Shane R. Premeaux \\ McNeese State University \\ Lake Charles, LA
}

\section{Introduction}

This investigation explores the influences of certain demographic and psychographic variables on consumer payment preferences. The important demographic factors include age, gender, education, income, occupation, marital status, race, religious beliefs and political affiliations (Rutledge and Callahan 1992; Slocum and Mathews 1975; Warren et al. 1990). In general, the psychographic factors normally considered include consumer attitudes toward different types of goods, credit orientation, price awareness, financial satisfaction, life styles, etc., (Kinnear and Taylor 1976; Lesser and Hughes 1986; Nunnally 1967; Tigert 1969; Wells 1975,1974). Currently, the preferred means of payment in the U.S. are cash, personal checks, charge accounts, and credit cards (Hirschman 1982). At the beginning of 1991, the number of credit cards issued by different banks was over 218 million, up from 161 million in 1985. These credit cards are used by over 60 million people in the United States (Mishkin 1992). In addition, 28 million T\&E cards were in circulation. Sears' Discover card, introduced in 1985, has grown to over 21 million accounts (Sinkey 1992). In this study, personal checks and cash are used synonymously because money in checking accounts is presumably as liquid as cash.

It is important to have a clear understanding of the relationship between consumer payment preferences and their demographic and psychographic attributes because the means of payment greatly influence the size, frequency and location of purchases. For example, credit cards are usually used to buy furniture, gasoline, household goods, electronics, and clothings, (Mandell 1972; Russell 1975; White 1975), while cash is usually used to buy food items.

Exclusive reliance on cash as a means of payment is found primarily among low-income families, and therefore their volume of check and credit-card expenditures is relatively low. Cash is generally used to make small dollar purchases and also to make purchases at remote locations (Avery et al. 1986; Hirschman 1982).

*The authors are deeply indebted to three anonymous referees for their invaluable comments and suggestions that led to a substantial qualitative improvement of the paper. However, the authors themselves are responsible for any remaining errors and deficiencies. Last but not least, the authors greatly appreciate Mrs. Bridgett Friend for her splendid typing work on this paper. 
Bank charge-cards are emerging fast as one of the newest mediums of exchange and credit in the U.S. economy. Unlike credit cards, the use of bank chargecards usually allows the consumer to obtain merchandise and borrow up to thirty days without interest. Bank charge-cards are primarily used for convenience and to meet emergency needs but not to make any big purchases for which the payment period exceeds 30 days (Awh and Waters 1974).

A great deal of research attention has been devoted to analyzing the patterns and determinants of consumer expenditures in terms of income, demographic and life style profiles (Plummer 1971; Warren et al. 1990). Several studies have also investigated consumer choices as they relate to alternative means of payment and various determinants thereof. But most of these earlier studies are descriptive and empirical without any significant discussions of implications. At least from that viewpoint, there exists a gap in the existing literature. In an earlier study, Avery et al. (1986) emphasized that families with annual incomes less than $\$ 10,000$, those with household heads with less than 12 years of education, and nonwhite or Hispanic families each use cash as their primary means of payment. Previous research also established that the use of all three payment methods rises in absolute terms with income, education, and the number of earners in the family. Clearly, household members substitute credit cards and charge cards for cash as income rises. On the contrary, low-income, less educated, older and non-white families are less likely to possess and/or use credit cards.

Significant marketing research has been conducted to enhance the understanding of consumer buying behavior, but little has been done with regard to consumer attitudes toward alternative means of payment. Prior payment research concentrated mainly on developing descriptive profiles of credit card users. A review of published literature reveals that research on cash and checking accounts as alternative means of payment is quite inadequate. However, at least one study found that consumers' perceptions of alternative means of payment and the attributes of users of various means of payment directly impacted their buying decisions (Hirschman 1982). Furthermore, Lindley et al. (1989) found that an increased tendency among household members to use credit cards, as a means of payment for both durable and nondurable goods, was dependent upon whether the family's decision-making process was joint or individual (Bass et al. 1968; Reiss 1981). For highly complicated decisions, and for decisions related to purchases of expensive goods or services joint-decision-making was most common (Menasco and Curry 1989).

Segmentation is a key tenant of marketing because certain segments of the population often behave quite differently. Segmentation commonly results from geographic, demographic, psychographic, and behavioristic factors. For instance, geographic location may lead to the formation of market segments comprised of customers from different geographic areas. Furthermore, the unique characteristics of each segment of the market may exert significant influences on consumer buying decisions and payment preferences (Etzel 1974; Rutledge and Callahan 1992). Further refinements in various market segmentation strategies based on the means of payment preference could result in more effective marketing strategies. 


\section{The Survey Design and Methodology}

The sampling frame for this study consists of families with preschoolers (ages 0 to 6). There are three primary reasons for selecting this stage of the family life cycle. First, families in this stage are very important to marketers because families with preschoolers, make up approximately 24 percent of the U. S. population. Second, the questionnaire response rate from families in the preschool age stage is normally high. In previous national surveys, families in this stage had the second highest response rate which reduces potential errors due to non-response bias. Third, such families are characterized by numerous financial strains, and the consumption process is directly related to these financial strains (Wind 1978; Wind and Green 1974). These strains may necessitate the use of alternate means of payment.

The data collection method consists of a telephone survey administered to 1,000 families in the preschool age stage of the family life cycle. Six hundred seventy-four of the respondents were found suitable for inclusion in this analysis. This sample consists of 565 whites and 109 nonwhites; 322 people had high school degrees and 352 had college degrees; 355 of the sample set were Catholics and 319 were noncatholics; there were 328 political conservatives and 346 political moderates and liberals; and 134 respondents had annual incomes of $\$ 20,000$ or less and 540 had annual incomes above $\$ 20,000$. The sampling frame was a list of randomly generated telephone numbers for the city of Lake Charles, Louisiana. Only residential telephone prefixes in service were included. The Lake Charles area was selected because its standard metropolitan statistical area is large enough to contain a diverse population which is presumed to offer a reasonably good representative sample.

The eligibility of respondents is determined by asking classification questions. If the household contains a married couple with one or more children under the age of six, they are selected as fitting into the preschool age stage of the family life cycle. Both husband and wife are asked to complete the questionnaire. The questionnaire is divided into two major sections with questions pertaining to family demographics and psychographics.

Since no prior research work is available to provide the exact time frame for questioning, the time frame is determined by the pilot study in which the questionnaire was pretested. As a result of this pretesting, the research instrument is customtailored to the preschool stage of the family life cycle.

Demographic variables were included because such factors have proven useful to marketers in their quest to understand better the consumer buying decision. Consequently, such variables should be of equal importance in promoting understanding in consumer payment preferences. The list of demographic variables considered in this study include gender, race, occupation, education, age, income, religious beliefs, and political affiliations.

Psychographic variables include the consumer life style, as determined by the respondents' orientation towards sports, the community and cultural activities; price awareness; brand loyalty; family togetherness; financial optimism; and satisfaction. 
Psychographic research is of particular importance to marketers, and this study solicits the opinions of family members to gather information on their activities, interests and shared perspectives of the world. Furthermore, psychographic variables often provide additional insight regarding the substantial differences among various groups of consumers in terms of payment preferences and buying decisions. These differences are often more profound than those produced by standard demographic profiles.

To determine the payment preference orientation of respondents, they were asked about the number of things they buy with a credit or charge card, the frequency of cash payments, their preference for having charge accounts, and their utilization experience with credit cards. Answers are rated on a four-point-evaluation-scale ranging from strongly agree to strongly disagree, with a "No Opinion" option. Limitations may exist because this study concentrates on one geographic area, which may not be representative of the total consumer population in the U.S.

The chi-square test was employed to investigate the null hypothesis of independence between demographic as well as psychographic variables (one variable considered at a time) and consumer payment preferences.

\section{Empirical Results}

The level of education appears to significantly influence consumer payment preference whereas race appears to have no discernible influence on consumer payment preference. However, gender plays some role in favor of cash purchases and consumer political affiliation was found to significantly impact payment preferences. Possibly, politically conservative individuals are financially more stable and economically more advanced so they are more likely to possess and use credit and charge cards. In contrast, religious beliefs show less influence in favor of the use of both cash and credit cards as means of payment. The empirical results are summarized in Table 1. It is somewhat obvious from these findings that astute marketers should adjust their marketing mixes to take into account payment preferences based on the consumer's level of education, income, gender, political affiliation, and, to a lesser degree, on religious beliefs.

Individuals with high school and college/university educations are more inclined to use charge and credit cards. On the other hand, the less educated use cash more frequently as a means of payment. The level of personal annual income significantly influences consumer payment preference. Respondents with annual incomes above 20,000 dollars are more likely to use charge and credit cards. In sharp contrast, those with incomes below 20,000 dollars per year prefer to use cash as a means of payment. Caucasians tend to use charge and credit cards more frequently than cash as a means of payment. However, non-Caucasians usually make relatively more cash purchases. Males and females are almost evenly split between the use of charge/credit cards and cash/personal checks as means of payment. Political conservatives and moderates use charge and credit cards more frequently than do liberals. Catholics and Protestants strongly prefer the possession and use of charge and credit cards as means 
of payment. Those of other religious faiths included in the sample (although very small in number) display very strong proclivities toward cash purchases.

Table 1 further reveals that within the broad category of psychographics, family togetherness or disjointness has no effect on having a charge card. However, the effect of these factors is considerable in favor of cash and credit cards as means of payment. Joint-buying decision-making strongly favors the use of credit cards and cash as means of payment. But it has no effect on charge card usage. Presumably, the desire to use charge cards is latent because of prolonged non-usage. Higher income expectations have a profound influence on all three methods of payment. Impatient/ impulsive buying behaviors have an even greater influence on all types of payment preference. Individuals who frequently travel have a stronger tendency to use charge and credit cards relative to cash and personal checks. Also, those who are easily enticed by newly introduced products appear to have no significant payment preference. More interestingly, families with children that fulfill the preschoolers' demands immediately have a strong preference for charge and credit card usage.

\section{Implications}

Individuals with higher levels of education and higher incomes, political conservatives, the economically more advanced and those with impatient buying habits are more likely to frequently use credit and charge cards to make purchases of relatively expensive durable goods, airline tickets and hotel accommodations. Furthermore, joint decision-making for large purchases frequently results in the use of credit and charge cards. Also, families with children are likely to use credit cards more often.

On the other hand, the less educated, the poor, and the vast majority of socioeconomically disadvantaged people are very likely to use cash/personal checks as a means of payment because it is difficult for them to obtain credit and charge cards. Because of their socioeconomic disadvantages they make relatively small purchases of basic necessities and simple goods and make few long distance trips. The poor and the less educated also live mostly in rural areas and inner cities, so their cash/check purchases take place either at relatively remote locations or at economically depressed areas. Religious faith appears to have no discernible influence on consumer payment preferences.

The above findings have multifarious implications for banks, credit card companies, marketers and retailers. As innovations take place and society advances economically and educationally, the market for credit cards expands. Because of such market expansions and yields of between 60 and 100 percent, commercial banks and credit card issuing companies must target the right groups of consumers to seize these market opportunities and enhance their profit potential (Sinkey 1992). Credit card revenue results from interest charges, annual fees, other customer charges, and interchange fees. Additionally, the issuance of credit cards in larger volumes and varieties will enable banks to enjoy economies of scale and scope. The use of cash is still high in economically depressed areas, among the poor, as well as among the less educated. 
Table 1

Summary of Empirical Results

\begin{tabular}{|c|c|c|c|c|}
\hline Demographics & d.f. & $\begin{array}{c}\text { Charge } \\
\text { Account } \\
\mathbf{X}^{2} \mathbf{c}\end{array}$ & $\begin{array}{r}\text { Cash } \\
\mathrm{X}^{2} \mathrm{c}\end{array}$ & $\begin{array}{c}\text { Credit } \\
\text { Cards } \\
\mathrm{X}^{2} \mathrm{c}\end{array}$ \\
\hline Education & 12 & $\begin{array}{l}45.992 \\
(\mathbf{a}, \mathrm{b}, \mathbf{c})^{*}\end{array}$ & $\begin{array}{l}39.376 \\
(\mathbf{a}, \mathbf{b}, \mathbf{c})^{*}\end{array}$ & $\begin{array}{l}39.353 \\
(\mathrm{a}, \mathrm{b}, \mathrm{c})^{*}\end{array}$ \\
\hline Income & 16 & $\begin{array}{r}31.507 \\
\text { (b.c) }\end{array}$ & $\begin{array}{l}53.219 \\
(\mathrm{a}, \mathrm{b}, \mathrm{c})^{*}\end{array}$ & $\begin{array}{l}64.361 \\
(\mathrm{a}, \mathrm{b}, \mathrm{c})^{*}\end{array}$ \\
\hline Race & 4 & 1.296 & 5.197 & 4.978 \\
\hline Gender & 4 & $\begin{array}{l}18.008 \\
(a, b, c)^{*}\end{array}$ & 1.558 & $\begin{array}{c}10.412 \\
\text { (c) }\end{array}$ \\
\hline Politics & 8 & 12.407 & 5.301 & 9.993 \\
\hline Religion & 8 & $\begin{array}{r}17.073 \\
\text { (c) }\end{array}$ & 14.088 & 11.674 \\
\hline \multicolumn{5}{|l|}{ Psychographics } \\
\hline Family Togetherness & 16 & 12.520 & $\begin{array}{l}31.538 \\
(b, c)^{*}\end{array}$ & $\begin{array}{c}28.787 \\
\text { (c) }^{*}\end{array}$ \\
\hline Joint Decision & 16 & 17.186 & 26.053 & 37.135 \\
\hline Higher Income Expecations & 16 & $\begin{array}{l}52.397 \\
(\mathrm{a}, \mathrm{b}, \mathrm{c})^{*}\end{array}$ & $\begin{array}{l}58.416 \\
(\mathrm{a}, \mathrm{b}, \mathrm{c})^{*}\end{array}$ & $\begin{array}{l}36.733 \\
(a, b, c)\end{array}$ \\
\hline Inpatient/Impulsive Buying & 16 & $\begin{array}{l}68.156 \\
(a, b, c)^{*}\end{array}$ & $\begin{array}{c}104.080 \\
(\mathrm{a}, \mathrm{b}, \mathrm{c})^{*}\end{array}$ & $\begin{array}{l}66.067 \\
(\mathrm{a}, \mathrm{b}, \mathrm{c})^{*}\end{array}$ \\
\hline Travel & 16 & $\begin{array}{c}76.961 \\
(\mathrm{a}, \mathrm{b}, \mathrm{c})^{*}\end{array}$ & $\begin{array}{l}59.744 \\
(\mathrm{a}, \mathrm{b}, \mathrm{c})^{*}\end{array}$ & $\begin{array}{l}74.007 \\
(\mathrm{a}, \mathrm{b}, \mathrm{c})^{*}\end{array}$ \\
\hline Attraction For New Things & 16 & $\begin{array}{l}71.509 \\
(\mathrm{a}, \mathrm{b}, \mathrm{c})^{*}\end{array}$ & $\begin{array}{l}77.933 \\
(\mathrm{a}, \mathrm{b}, \mathrm{c})^{*}\end{array}$ & $\begin{array}{c}67.153 \\
(\mathrm{a}, \mathrm{b}, \mathrm{c})^{*}\end{array}$ \\
\hline $\begin{array}{l}\text { Buying Dominance of } \\
\text { Children }\end{array}$ & 16 & $\begin{array}{l}50.435 \\
(\mathrm{a}, \mathrm{b}, \mathrm{c})^{*}\end{array}$ & $\begin{array}{r}33.062 \\
(\mathrm{~b}, \mathrm{c})^{*}\end{array}$ & $\begin{array}{l}36.382 \\
(\mathrm{a}, \mathrm{b}, \mathrm{c})^{*}\end{array}$ \\
\hline
\end{tabular}

*In parentheses for two-tailed cases a, b, and c denote statistical significance at 99, 95 and 90 percent confidence intervals respectively. 
Smaller banks have an opportunity to extend retail services to these consumers at convenient locations. Effective market segmentation may improve the chance of their survival because they cannot compete with larger banks which tend to dominate the market for credit and charge cards.

Large retailers of durable, luxury and complicated expensive goods, the airlines, hotel and restaurant businesses, providers of services in large volumes, international business firms, manufacturers should devise marketing strategies to satisfy the needs and aspirations of the credit card holders and users. Because people use charge cards to meet emergency needs and for convenience, marketers and retailers should tailor their strategies to better satisfy such needs.

Small businesses may concentrate on sales promotions at remote locations and to the poor, as well as the less educated, who prefer to use cash/personal checks as a means of payment. When small businesses cannot compete with larger ones, they may enhance their profitability by addressing the needs of a specific group of consumers. However, speciality goods would be an exception because they are usually purchased by the economic and social elites.

Manufacturers of expensive toys and producers of new model autos, electronic goods and computers may target families with children, joint-decision-making families, and impatient buyers with economic surpluses or credit. Again, these people have a greater tendency to use credit and charge cards and therefore should constitute the target group of customers for the above items.

These findings also have implications for the U.S. Federal Reserve System that is in charge of U.S. monetary policy. The monetary policy-makers need to keep track of changes in consumption patterns and consumer payment preferences to help predict the velocity of money and the money demand in order to determine the country's total money supply (Mishkin 1992). A mismatch between money demand and money supply will trigger price instability and produce economic zig-zags. The conventional definitions of money and money supply aggregates need some refinements due to continuing financial innovations. All these changes are bound to impact the financial markets through factors such as interest rate changes and economic cycles. A better understanding of changes in consumer payment preferences may provide some preludes to re-evaluate the mechanics of monetary policy formulations.

Again, any changes in consumer payment preferences are conditional upon variations in demographic and psychographic variables. Sometimes these changes go unnoticed and therefore there is an undeniable need for periodic investigation of such issues. Caution must be exercised in generalizing these findings because of the limited geographic representation. However, these findings supplement the existing body of knowledge in this area. 


\section{References}

Avery, Robert B., Gregory E. Elliehausen, Arthur B. Kennickell, and Paul A. Spindt. 1986. "The Use of Cash and Transaction Accounts by American Families." Federal Reserve Bank Bulletin_(February): 87-108.

Awh, R.V. and D. Waters. 1974. "A Discriminant Analysis of Economic, Demographic and Attitudinal Characteristics of Bank Charge-Card Holders: A Case Study." Journal of Finance 29: 973-80.

Bass, Fran M., Douglas J. Tigert, and Ronald T. Lonsdale. 1968. "Market Segmentation: Group versus Individual Behavior.” Journal of Marketing Research 5: 264-70.

Etzel, Michael. 1974. "Using Multiple Discriminant Analyses to Segment the Consumer Credit Market." In Combined Proceedings. Ed. Ronald C. Curhan. Chicago: American Marketing Association.

Hirschman, Elizabeth C. 1982. "Consumer Payment Systems: The Relationship of Attribute Structure To Preference and Usage." Journal of Business 55: 531-45.

Kinnear, Thomas C. and James R. Taylor. 1976. "Psychographics: Some Additional Find ings." Journal of Marketing Research 13: 422-25.

Lesser, Jack A. and Marie A. Hughes. 1986. "Psychographic Market Segments Across Geographic Locations.” Joumal of Marketing_50: 18-27.

Lindley, James T., Patricia Rudolph, and Edward B. Selby, Jr. 1989. “Credit Card Possession And Use: Changes Over Time.” Journal of Economics and Business 41: 127-42.

Mandell, Lewis. 1972. Credit Card Use in the United States. Ann Arbor, Michigan: Institute for Social Research.

Menasco, Michael B. and David J. Curry. 1989. "Utility and Choice: An Empirical Study of Wife/Husband Decision Making.” Journal of Consumer Research_16: 87-97.

Mishkin, Frederic S. 1992. The Economics of Money, Banking and Financial Institutions. Third Edition. New York: Harper-Collins Publishers.

Nunnally, Jum C. 1967. Psychometric Theory. New York: McGraw-Hill Book Company. Plummer, Joseph T. 1971. "Life Style Patterns and Commercial Bank Credit Card Usage." Journal of Marketing 35: 35-41. 
Fall 1994 Rahman, et al:Influences of Demo. \& Psycho. on Consumer Pref.

Reiss, D. 1981. The Family's Construction of Reality. Cambridge: Harvard University Press.

Russell, Thomas. 1975. The Economics of Bank Credit Cards. New York: Praeger.

Rutledge, Dan and Thomas Callahan. 1992. "Geo-Demographic Market Segmentation: An Application in Marketing Management." Journal of Business Strategies 9: 124-36.

Sinkey, Joseph F., Jr. 1992. Commercial Bank Financial Management. Fourth Edition. New York: Macmillan Publishing Company.

Slocum, John W., Jr. and H. Lee Mathews. 1975. "Social Class and Income as Indicators of Consumer Credit Behavior." Journal of Marketing 35: 59-74.

Tigert, Douglas J. 1969. "Psychographics: A Test-Retest Reliability Analysis." In Marketing Involvement in Society and the Economy. Ed. P.R. McDonald. Chicago: American Marketing Association, 310-15.

Warren, William E., Robert E. Stevens, and William McConkey. 1990. "Using Demographic and Lifestyle Analysis to Segment Individual Investors." Financial Analyst Journal 46: 74-77.

Wells, William D. 1975. "Psychographics: A Critical Review." Journal of Marketing Reseatch 12: 196-211.

- - - 1974. Life Style and Psychographics. Chicago: American Marketing Association.

White, Kenneth J. 1975. "Consumer Choice and Use of Bank Credit Cards: A Model and Cross-Section Results." Journal of Consumer Research 2: 10-18.

Wind, Jerry and Paul Green. 1974. "Some Conceptual, Measurement and Analytic Problems in Life Style Research." In Life Style and Psychographics. Ed. William D. Wells. Chicago: American Marketing Association, 99-126.

Wind, Yoram. 1978. "Issues and Advances in Segmentation Research." Journal of Marketing Research 15: 324-25. 